\title{
Phosphate Reduction in Emulsified Meat Products: Impact of Phosphate Type and Dosage on Quality Characteristics
}

\author{
Seline Glorieux ${ }^{1,2}$, Olivier Goemaere ${ }^{1}$, Liselot Steen ${ }^{1}$ and Ilse Fraeye ${ }^{1 *}$ \\ ${ }^{1}$ KU Leuven Technology Campus Ghent, Leuven Food Science and Nutrition Research Centre (LFoRCe), \\ Research Group for Technology and Quality of Animal Products, Gebroeders De Smetstraat 1, \\ BE-9000 Gent, Belgium \\ ${ }^{2}$ KU Leuven Kulak, Leuven Food Science and Nutrition Research Centre (LFoRCe), Foods \& Lipids, \\ Etienne Sabbelaan 53, BE-8500 Kortrijk, Belgium \\ Received: November 29, 2016 \\ Accepted: May 9, 2017
}

\begin{abstract}
Summary
Phosphate reduction is of important industrial relevance in the manufacturing of emulsified meat products because it may give rise to a healthier product. The effect of seven different phosphate types was tested on the physicochemical and quality characteristics to select the most promising phosphate type for further cooked sausage manufacturing. Next, phosphate mass fraction was gradually reduced. Tetrasodium di- or pyrophosphate (TSPP) and sodium tripolyphosphate (STPP) increased $\mathrm{pH}$, reduced structural properties, resulted in the highest emulsion stability, lowest cooking loss and had little effect on hardness. Based on the viscoelastic properties, a minimum mass fraction of $0.06 \%$ TSPP was sufficient to obtain an acceptable quality product. Rheology proved to be a very useful tool to evaluate the quality of meat products, as it gives insight in the structure of the meat product and especially the functional properties of meat proteins. Based on the obtained results, it can be concluded that the current amount of phosphate added to emulsified meat products can be significantly reduced with minimal loss of product quality.
\end{abstract}

Key words: phosphate type, phosphate reduction, viscoelastic properties, quality characteristics, cooked sausage

\section{Introduction}

Phosphates occur naturally in the form of organic esters in many kinds of food, including meat. These phosphate esters are organically bound and only partially absorbed in the gastrointestinal tract. Phosphates are important for human health since they are responsible for growth, maintenance and repair of tissues and cells of living organisms. However, an avoidable risk to health arises from the increased use of phosphates as food additives and preservatives. These 'free' (not organically bound) phosphates are effectively absorbed in the gastrointestinal tract. An association was found between high intake of phosphate additives and cardiovascular morbidity and mortality (1). This was already recognized in chronic kidney disease patients but questions arise with regard to the general population $(1,2)$.

Phosphates in the meat industry are used as sodium or potassium salts of phosphoric acid. Depending on the number of phosphorus atoms, phosphates can be divided into mono- or orthophosphates $\left(\mathrm{PO}_{4}^{3-}\right.$, e.g. mono-, di- and trisodium phosphate (MSP, DSP and TSP respectively)), di- or pyrophosphates $\left(\mathrm{P}_{2} \mathrm{O}_{7}^{4-}\right.$, e.g. tetrasodium pyrophos-

\footnotetext{
*Corresponding author: Phone: +329 265 8728; Fax: +329 265 8638; E-mail: Ilse.Fraeye@biw.kuleuven.be Co-first authorship: S. Glorieux and O. Goemaere 
phate (TSPP) and sodium acid pyrophosphate (SAPP)), triphosphates $\left(\mathrm{P}_{3} \mathrm{O}_{10}{ }^{5-}\right.$, e.g. sodium tripolyphosphate (STPP)) and polyphosphates $\left(\mathrm{P}_{\mathrm{n}} \mathrm{O}_{3 \mathrm{n}+1}{ }^{(\mathrm{n}+2)-}\right.$, e.g. sodium hexametaphosphate (SHMP)) (2,3). According to the European legislation, food phosphates are not permitted in fresh meat and may be added in a maximum amount of $0.5 \%$ (expressed as $\left.\mathrm{P}_{2} \mathrm{O}_{5}\right)$ to meat products $(1,2,4)$.

The chemical formula, $\mathrm{pH}$, solubility, E number and relative content of $\mathrm{P}_{2} \mathrm{O}_{5}$ (in \%) of several phosphate types have recently been presented (2). Phosphates fulfil different functional properties in meat products and can have an impact on $\mathrm{pH}$, chelation, ionic strength and antibacterial activity $(2,3,5,6)$. Monophosphates have a good buffering capacity but have no effect on muscle proteins (2). Diphosphates (especially TSPP) have the ability to dissociate the actomyosin complex of meat immediately, and tri- and polyphosphates help to activate meat proteins by partially chelating protein-bound $\mathrm{Mg}^{2+}$ and $\mathrm{Ca}^{2+}$, both leading to increased solubilization of myosin and actin and depolymerization of thick and thin filaments (7). As such, these proteins can maximally exert their emulsifying and gelling properties, which are very important with regard to the fat and water stabilization $(8,9)$. However, due to their low solubility, di- and triphosphates cannot be used in brine. In this case more soluble, long-chain polyphosphates (such as SHMP) are applied, e.g. in the preparation of whole muscle meat products such as cooked ham. In addition, the buffering capacity of some phosphate types can contribute to their functionality in meat. Water holding capacity (WHC) is greatly affected by $\mathrm{pH}$, and is at its minimum at the isoelectric point (pI). The $\mathrm{pI}$ of meat proteins is in the $\mathrm{pH}$ range \pm 5.5 , which is also the meat $\mathrm{pH}$ after rigor mortis. Increasing $\mathrm{pH}$ away from the pI will result in increased WHC. Addition of alkaline phosphates (e.g. TSPP and STPP) during the manufacturing of meat products will increase the $\mathrm{pH}$ in the slightly acidic meat. This increase in the $\mathrm{pH}$ will result in electrostatic repulsion between or within the meat proteins, resulting in higher WHC. Apart from the $\mathrm{pH}$ effect, WHC can also be increased due to a change in ionic strength. Phosphates affect ionic strength by forming polyelectrolytes in water, causing electrostatic repulsion between the meat proteins, which allows more space for binding water and hence, increased WHC. This is especially true for polyphosphates (e.g. SHMP). This also supports immobilization of water and the emulsification of fat (3). Phosphates are not considered as direct preservatives but have a slight bacteriostatic effect and they also have an antioxidant effect $(2,3,10-12)$.

$\mathrm{NaCl}$ has a positive effect on the water binding of myofibrillar proteins (13), as it is able to increase myofibrillar protein solubility. A minimum concentration of $0.6 \mathrm{M}$ is required to extract myofibrillar proteins out of the myofibril, but lower $\mathrm{NaCl}$ concentrations are needed when SAPP or STPP are added to achieve a similar extraction effect $(14,15)$.

In the last 20 years, many phosphate types and their mixtures (blends) have been studied in meat and meat products (2). Four different phosphate types, mainly TSPP, STPP, SHMP and SAPP, are typically discussed. Globally, most studies used only one phosphate type (1620). Studies that compared two or more phosphate types are outnumbered (21-24). Moreover, the effect of phosphate type and/or blends was mainly tested on sensorial or physicochemical properties such as colour and $\mathrm{pH}(23-$ 24). The effect of phosphate type on quality characteristics such as texture and cooking loss remained limited to studies concerning restructured pork (25), buffalo meat and patties (21), beef (22) and goat meat and restructured goat meat products (26) while, to the best of our knowledge, no studies have been conducted concerning the use of different phosphate types in cooked pork sausages.

Studies about different phosphate levels, whether or not in combination with other substances (such as carrageenan or gum) in meat and meat products have also been discussed (2). The effect of phosphate reduction in meat or meat products was already evaluated in terms of phosphate diffusion, colour development, sensory attributes and cooking yield $(27,28)$. Studies about the effect of different phosphate levels without other additives on quality characteristics are limited to smoked ham (29), beef meat $(22,23)$ and red meat $(17)$. Only one study has been found that evaluates the effect of meat and phosphate level on WHC and texture of emulsion-type pork sausages during storage (30). The combined effects of $\mathrm{NaCl}$ and raw meat $\mathrm{pH}$ on WHC in cooked pork/beef sausages with or without added phosphate were studied (31). However, the authors did not gradually lower the amount of phosphate to study the effect of phosphate content.

Therefore, the aim of this study is to reduce the amount of phosphate in emulsified meat products and still maintain a high-quality product. Phosphate reduction is of important industrial relevance in the manufacturing of emulsified meat products because it may give rise to a healthier meat product. First, the effect of seven different phosphate types was tested on the physicochemical (colour and $\mathrm{pH}$ ) and quality characteristics (structural and textural properties, emulsion stability and cooking loss), so that the most promising phosphate type could be selected for further cooked sausage manufacturing. Next, the amount of phosphate was reduced (5 different mass fractions) and physicochemical and quality characteristics were again evaluated. Importantly, throughout the study attention was given to the effect of phosphate on the rheological properties of the meat batter, which has not been studied before in literature. This technique allows increased insight into the mechanism of action of the different phosphates.

\section{Materials and Methods}

\section{Manufacturing of cooked sausage}

Cooked sausages were prepared in the pilot plant of the research group Technology and Quality of Animal Products (KU Leuven Technology Campus Gent, Gent, Belgium). Pork shoulder and pork backfat were obtained from a local industrial slaughterhouse (De Lausnay Rene BVBA, Destelbergen, Belgium). Raw materials were chopped, homogenized to generate one batch, vacuum-packed and stored at $-18{ }^{\circ} \mathrm{C}$ until preparation (within a three-month period). All food additives were bought from Solina Group (Eke-Nazareth, Belgium). Cooked sausages were produced with (in g per $100 \mathrm{~g}$ ): pork shoulder 40 , pork backfat 35 
and ice 25, together with nitrite curing salt 1.8 , phosphate (see Table 1), sugar 0.5, white pepper 0.2 , foil 0.05 , ascorbic acid 0.05 , glutamate 0.05 , coriander 0.025 and cardamom 0.025. All ingredients were calculated in relation to the total mass of raw materials (pork shoulder and pork backfat) and ice.

Table 1. Dosage of different phosphate types

\begin{tabular}{ccc}
\hline Phosphate & $w\left(\mathrm{P}_{2} \mathrm{O}_{5}\right) / \%$ & $w /(\mathrm{g} / 100 \mathrm{~g})$ \\
\hline MSP & 45.49 & 0.38 \\
DSP & 39.87 & 0.43 \\
TSP & 19.21 & 0.89 \\
TSPP & 53.38 & 0.32 \\
SAPP & 64.03 & 0.27 \\
STPP & 57.91 & 0.30 \\
SHMP & 69.61 & 0.25 \\
\hline
\end{tabular}

The $\mathrm{P}_{2} \mathrm{O}_{5}$ content of each phosphate type differs (second column) and results in a different dosage (third column). MSP, DSP, TSP=mono-, di- and trisodium phosphate, respectively, TSPP=tetrasodium di- or pyrophosphate, $\mathrm{SAPP}=$ sodium acid pyrophosphate, $\mathrm{STPP}=$ sodium tripolyphosphate and SHMP=sodium hexametaphosphate

First, the raw meat (pork shoulder) was chopped together with the ice, salt and phosphate in a bowl cutter (model UM12; Stephan Machinery GmbH, Hameln, Germany) for $7.5 \mathrm{~min}$. Next, the pork backfat was added to the meat batter in the cutter together with the remaining food additives. The total mass was cut under vacuum for 3 min to obtain a homogenous batter. Temperature did not exceed $14{ }^{\circ} \mathrm{C}$ during processing to avoid protein denaturation and fat coalescence. Part of the batter was immediately analyzed for emulsion stability and structural properties. In order to standardize the production and cooking process, the remainder of the batter was filled into cans of standardized dimensions $(d=7 \mathrm{~cm}, h=5 \mathrm{~cm}$, $m \sim 250$ g; Crown Verpakking Belgie NV, Hoboken, Belgium) rather than casings, cooked at $76^{\circ} \mathrm{C}$ (core temperature $72{ }^{\circ} \mathrm{C}$ ) in a cooking chamber (Rational Climaplus Combi ${ }^{\circledR}$ CPC 61; Claes Machines, Paal, Belgium) and finally cooled to $4{ }^{\circ} \mathrm{C}$. The resulting meat products, cooked in cans, served as a model product for cooked sausage. Therefore, throughout the text these products are referred to as cooked sausages. One week after the manufacturing, $\mathrm{pH}$, colour, cooking loss and textural properties of cooked sausages were analyzed.

During the first part of our research, seven different phosphate types were tested. Each sausage formulation contained $0.17 \% \mathrm{P}_{2} \mathrm{O}_{5}$, which is a standard amount used in the meat industry for emulsified meat products. The mass fraction of $\mathrm{P}_{2} \mathrm{O}_{5}$ in each phosphate differs (Table 1, second column), which resulted in a different dosage (Table 1, third column). A product without phosphate was also processed and used as non-phosphate control product.

After evaluating the quality characteristics of the cooked sausages prepared with different phosphate types (Table $1)$, the phosphate type that contributed most to the quali- ty characteristics of the cooked sausage was used in the second part of our research, in which the mass fraction of $\mathrm{P}_{2} \mathrm{O}_{5}$ was reduced from 0.17 to respectively $0.11,0.06,0.03$ and $0.01 \%$. The product without phosphate prepared during the first part was also used as control. Cooked sausages were prepared in triplicate per recipe.

\section{Dynamic viscoelastic properties}

Rheological measurements of sausage batters were performed using an AR2000ex controlled-stress rheometer (TA Instruments, New Castle, DE, USA) equipped with a 40-mm parallel plate system. A crosshatched upper and lower plate were used to prevent slippage of the sample. The gap was set at $1000 \mu \mathrm{m}$. The AR2000ex was supplemented with an efficient Peltier temperature control system and upper heated plate (TA Instruments) to control the sample temperatures accurately.

Oscillation experiments were conducted at $13{ }^{\circ} \mathrm{C}$. A 5 -minute delay was set after transferring the samples to the rheometer, allowing the stress induced in the sample during sample loading to relax. Excess material was wiped off with a spatula before analysis.

Stress sweeps between 0.1 and $1000 \mathrm{~Pa}$ at a fixed frequency of $1 \mathrm{~Hz}$ were performed to determine the linear viscoelastic region (LVR). The 'storage' and 'loss' moduli $\left(G^{\prime}\right.$, a measure of elastic property and $G^{\prime \prime}$, a measure of viscous property, respectively) and the 'phase angle' $(\delta)$ were directly obtained from the software (32). The $\delta=90^{\circ}$ represents a fully viscous material, while a fully elastic material is characterized by $\delta=0^{\circ}(33)$. The complex modulus $\left(G^{*}\right)$, the ratio of the total tension to the deformation, was calculated as follows:

$$
G^{*}=\sqrt{\left(G^{\prime 2}\right)+\left(G^{\prime \prime 2}\right)}
$$

$G^{*}$ represents the material overall rigidity or resistance to deformation. The stress range over which both $G^{\prime}$ and $G^{\prime \prime}$ are independent of the applied stress amplitude is called LVR. Within this region, the structure is intact. The LVR was calculated from the stress sweep curves as the stress level at which $G^{*}$ deviates more than $5 \%$ from a constant $G^{*}$ (plateau) value. More than $5 \%$ deviation implicates an irreversible structure breakdown.

\section{Emulsion stability}

Emulsion stability was determined according to Hughes et al. (34). Raw sausage batter (30 g) was placed in a pre-weighed centrifuge tube (VWR International, Leuven, Belgium) and the initial mass of the sample was registered. The sample was heated in a cooking chamber (30 min, $70{ }^{\circ} \mathrm{C}$ ) and centrifuged $\left(4230 \times g, 3 \mathrm{~min}, 25^{\circ} \mathrm{C}\right.$, model 320R; Hettich Universal, Newport Pagnell, UK). The drip loss (supernatant containing a mixture of water and fat) was weighed (aluminium weighing dishes; VWR International). The percentage of total expressible fluid $(\mathrm{TEF} / \%)$ was calculated by the following equation:

$$
\mathrm{TEF}=\left(\frac{m_{\text {drip loss }}}{m_{\text {sample }}}\right) \cdot 100
$$

\section{Cooking loss}

One week after processing, cooking loss (CL/\%) was calculated by determining the initial sausage mass and 
drip loss (jelly and fat separation). CL was expressed as follows:

$$
\mathrm{CL}=\left(\frac{m_{\text {drip loss }}}{m_{\text {sample }}}\right) \cdot 100
$$

\section{Colour and $\mathrm{pH}$ measurements}

The instrumental colour analysis was based on the 3-dimensional CIELAB colour scale. After a week of cold storage, the colour of the freshly broached cooked sausages was measured by a portable reflectance colourimeter Miniscan EZ 4500L $45^{\circ} / 0^{\circ}$ (Hunterlab, Murnau, Germany) with 8-mm viewing area size. Illuminant D65 and a $10^{\circ}$ standard observer were used to register the $L^{*}$ (lightness), $a^{*}$ (redness), and $b^{*}$ (yellowness) values, with one channel for $L^{*}$, ranging from black $\left(L^{*}=0\right)$ to white $\left(L^{*}=\right.$ 100), and two channels for $a^{*}$, ranging from red $\left(+a^{*}\right)$ to green $\left(-a^{*}\right)$, and $b^{*}$, ranging from yellow $\left(+b^{*}\right)$ to blue $\left(-b^{*}\right)$.

The $\mathrm{pH}$ value was measured with a portable meat $\mathrm{pH}$ meter (model HI 99163; HANNA, Nieuwegein, the Netherlands) inserted into the cooked sausage.

\section{Texture}

Hardness of the cooked sausages was evaluated using a Lloyd texture analyser (model TA Plus; Lloyd Instruments, Bognor Regis, UK). Cans with cooked sausage were axially penetrated to a depth of $2 \mathrm{~cm}$ using a load cell of $100 \mathrm{~N}$ and a cylindrical probe $(d=6 \mathrm{~mm}$; Lloyd Instruments) at a speed of $100 \mathrm{~mm} / \mathrm{min}$. Hardness was directly obtained from the recorded force-distance curves and described as the maximum force $(\mathrm{N})$ to penetrate the sample.

\section{Statistical analysis}

All analyses were performed in triplicate on each sausage sample. Results are expressed as mean value \pm stan- dard deviation. Statistical analysis was performed using IBM SPSS Statistics v. 22 (35). All results were evaluated by one-way ANOVA. A Tukey's post hoc test was performed and a significance level of $\mathrm{p}<0.05$ was used to identify significant differences.

\section{Results and Discussion}

\section{Impact of phosphate type on the quality characteristics of cooked sausages}

Structural properties of cooked sausages influenced by phosphate type

The structural properties of all meat batters were rheologically analysed. As already mentioned in section Dynamic viscoelastic properties, $\delta=90^{\circ}$ represents a fully viscous material, while a fully elastic material is characterized by $\delta=0^{\circ}$. The linear viscoelastic region (LVR) reflects the stress range in which the structure of the sample remains intact. However, when the applied deformation increases, irreversible structure breakdown occurs. High $G^{*}$ values indicate a high resistance to deformation and a system having 'more' structure.

Data in Table 2 indicate that the LVR of the sausage batter was the highest in the control or SHMP samples. When no phosphate was added (control), the actomyosin complex was still intact and more capable of resisting external deformation. SHMP, a long chain polyphosphate, is mostly used in phosphate blends because of its high solubility, but it has no ability to dissociate the actomyosin complex and therefore, the actomyosin complex is also still intact. It is suggested that the high LVR in these samples reflects an intact actomyosin complex due to which it can withhold higher stress before structure deformation occurs (36). When using monophosphates (MSP, DSP and

Table 2. Significant differences at $\mathrm{p}<0.05$ of the physicochemical (colour and $\mathrm{pH}$ ) and quality characteristics (structural and textural properties, emulsion stability and cooking loss) of pork sausages with different phosphate types $(N=3)$

\begin{tabular}{|c|c|c|c|c|c|c|c|c|}
\hline Phosphate type & NP & MSP & DSP & TSP & TSPP & SAPP & STPP & SHMP \\
\hline \multicolumn{9}{|c|}{ Structural properties } \\
\hline LVR/Pa & $(34.9 \pm 4.7)^{\mathrm{ab}}$ & $(29.1 \pm 5.3)^{\mathrm{bc}}$ & $(28.7 \pm 4.0)^{c}$ & $(28.0 \pm 2.6)^{\mathrm{c}}$ & $(6.60 \pm 0.86)^{\mathrm{e}}$ & $(13.7 \pm 2.9)^{\mathrm{d}}$ & $(8.6 \pm 1.1)^{\mathrm{de}}$ & $(36.5 \pm 2.4)^{\mathrm{a}}$ \\
\hline$G^{*} / 10^{1} \mathrm{~Pa}$ & $(733 \pm 40)^{\mathrm{c}}$ & $(867 \pm 89)^{\mathrm{b}}$ & $(878 \pm 52)^{\mathrm{b}}$ & $(1012 \pm 53)^{a}$ & $(288 \pm 45)^{\mathrm{de}}$ & $(379 \pm 26)^{d}$ & $(240 \pm 68)^{\mathrm{e}}$ & $(691 \pm 38)^{c}$ \\
\hline$\delta /^{\circ}$ & $(13.26 \pm 0.35)^{\mathrm{d}}$ & $(13.67 \pm 0.53)^{\mathrm{d}}$ & $(12.39 \pm 0.12)^{\mathrm{d}}$ & $(11.78 \pm 0.26)^{\mathrm{d}}$ & $(29.44 \pm 1.4)^{\mathrm{a}}$ & $(21.67 \pm 0.61)^{\mathrm{b}}$ & $(29.32 \pm 3.51)^{\mathrm{a}}$ & $(17.25 \pm 0.36)^{c}$ \\
\hline \multicolumn{9}{|l|}{ Stability } \\
\hline $\mathrm{TEF} / \%$ & $(9.9 \pm 2.0)^{\mathrm{bc}}$ & $(15.5 \pm 2.0)^{\mathrm{a}}$ & $(8.3 \pm 2.6)^{\mathrm{cd}}$ & $(10.9 \pm 1.8)^{\mathrm{b}}$ & $(6.6 \pm 1.2)^{\mathrm{d}}$ & $(10.5 \pm 1.6)^{b}$ & $(6.5 \pm 1.1)^{\mathrm{d}}$ & $(9.41 \pm 0.95)^{\mathrm{bc}}$ \\
\hline $\mathrm{CL} / \%$ & $(6.33 \pm 0.72)^{\mathrm{b}}$ & $(7.28 \pm 0.92)^{\mathrm{a}}$ & $(1.65 \pm 0.51)^{\mathrm{d}}$ & $(1.40 \pm 0.52)^{\mathrm{de}}$ & $(0.65 \pm 0.40)^{\mathrm{e}}$ & $(3.37 \pm 0.59)^{c}$ & $(0.71 \pm 0.16)^{\mathrm{de}}$ & $(2.90 \pm 0.84)^{c}$ \\
\hline \multicolumn{9}{|c|}{ Physicochemical properties } \\
\hline$L^{*}$ & $(76.66 \pm 0.43)^{\mathrm{ab}}$ & $(76.37 \pm 0.24)^{\mathrm{bc}}$ & $(75.82 \pm 0.31)^{\mathrm{de}}$ & $(75.77 \pm 0.39)^{\mathrm{e}}$ & $(76.11 \pm 0.53)^{\mathrm{cd}}$ & $(76.79 \pm 0.48)^{\mathrm{a}}$ & $(76.67 \pm 0.43)^{\mathrm{ab}}$ & $(76.64 \pm 0.36)^{\mathrm{ab}}$ \\
\hline$a^{*}$ & $(8.12 \pm 0.28)^{\mathrm{b}}$ & $(8.21 \pm 0.13)^{\mathrm{ab}}$ & $(8.07 \pm 0.19)^{\mathrm{b}}$ & $(7.734 \pm 0.24)^{c}$ & $(8.25 \pm 0.23)^{\mathrm{ab}}$ & $(8.24 \pm 0.20)^{\mathrm{ab}}$ & $(8.22 \pm 0.23)^{\mathrm{ab}}$ & $(8.31 \pm 0.28)^{a}$ \\
\hline$b^{*}$ & $(12.39 \pm 0.24)^{a}$ & $(12.49 \pm 0.18)^{a}$ & $(12.48 \pm 0.23)^{\mathrm{a}}$ & $(12.60 \pm 0.34)^{\mathrm{a}}$ & $(12.47 \pm 0.26)^{a}$ & $(12.45 \pm 0.30)^{\mathrm{a}}$ & $(12.49 \pm 0.23)^{\mathrm{a}}$ & $(12.50 \pm 0.26)^{\mathrm{a}}$ \\
\hline $\mathrm{pH}$ & $(6.01 \pm 0.11)^{\mathrm{e}}$ & $(5.96 \pm 0.06)^{\mathrm{e}}$ & $(6.53 \pm 0.04)^{\mathrm{b}}$ & $(7.42 \pm 0.01)^{\mathrm{a}}$ & $(6.44 \pm 0.05)^{c}$ & $(5.70 \pm 0.15)^{\mathrm{f}}$ & $(6.21 \pm 0.02)^{\mathrm{d}}$ & $(6.16 \pm 0.07)^{\mathrm{d}}$ \\
\hline
\end{tabular}

Textural properties

\begin{tabular}{|c|c|c|c|c|c|c|c|c|}
\hline Hardness/N & $(8.2 \pm 1.5)^{\mathrm{b}}$ & $(9.7 \pm 1.5)^{\mathrm{a}}$ & $(8.0 \pm 0.8)^{b}$ & $(8.1 \pm 0.8)^{\mathrm{b}}$ & $(7.8 \pm 0.9)^{\mathrm{b}}$ & $(10.1 \pm 1.3)^{\mathrm{a}}$ & $(8.1 \pm 0.7)^{b}$ & $(8.4 \pm 0.9)^{b}$ \\
\hline
\end{tabular}

$\mathrm{NP}=$ control, MSP, DSP, TSP=mono-, di- and trisodium phosphate, respectively, $\mathrm{TSPP}=$ tetrasodium di- or pyrophosphate, $\mathrm{SAPP}=$ sodium acid pyrophosphate, $\mathrm{STPP}=$ sodium tripolyphosphate and $\mathrm{SHMP}=$ sodium hexametaphosphate, $\mathrm{LVR}=$ linear viscoelastic region, $G^{*}=$ complex modulus, Eq. $1, \delta=$ phase angle, TEF=total expressible fluid, Eq. $2, \mathrm{CL}=$ cooking loss, Eq. $3, L^{*}=$ lightness, $a^{*}=$ redness and $b^{*}=$ yellowness 
TSP), the LVR decreased slightly compared to the control or SHMP preparation. Preparations without phosphate or with MSP, DSP and TSP had the lowest $\delta$ values and reflect a more 'solid-like' behaviour. When monophosphates MSP, DSP and TSP were added, $G^{*}$ was significantly $(p<0.05)$ higher than with the other phosphate types, reflecting 'more' structure and higher resistance to deformation. In contrast, the LVR was the lowest when TSPP, SAPP and STPP were added. It can be suggested that because TSPP, SAPP and STPP do have the ability to split the actomyosin complex, the sausage batter was more sensitive to external deformation. This is also translated in the $G^{*}$ and $\delta$ values. Significantly $(\mathrm{p}<0.05)$ lower $G^{*}$ and higher $\delta$ values when using TSPP, SAPP and STPP were observed, reflecting 'less' structure, lower resistance to deformation and a more 'liquid-like' behaviour. These effects were more pronounced in case of TSPP and STPP than of SAPP.

In a recent study, the addition of salt to a liver batter significantly decreased the LVR (36). The authors concluded that $\mathrm{NaCl}$ dissolved the myofibrillar proteins and changed their original structure, leading to a more viscous-like and sensitive structure. The results could be more or less compared, keeping in mind that $\mathrm{NaCl}$ also affects protein functionalities like solubility, extractability, emulsifying and gelation properties (13). Apart from the former study, no comparison with literature could be made concerning the effect of phosphate type on structural properties of sausage batters or related products.

The loss of structure of the sausage batter due to breakdown of the actomyosin complex is interesting because it indicates that myosin is released from the actomyosin complex and presumably can act as a natural emulsifier and participate in the gelation process, which is crucial for the stabilization of fat and water in emulsified meat products. In this respect, rheological analysis of the meat batter provides an interesting tool in understanding how the sausage batter is influenced by its composition and processing.

\section{Effect of phosphate type on the $\mathrm{pH}$ of cooked sausages}

Data in Table 2 also show that phosphate type had a significant $(\mathrm{p}<0.05)$ effect on $\mathrm{pH}$ value. Preparations with TSP had the highest $\mathrm{pH}$ value, while the addition of SAPP resulted in the lowest $\mathrm{pH}$ value. The $\mathrm{pH}$ increased by 1.41 units and decreased by 0.31 units when using TSP and SAPP respectively, compared to the preparation without phosphate (control). This result was expected since TSP and SAPP have the most alkaline and acid $\mathrm{pH}$ respectively, as compared to the other tested phosphate types (2). The $\mathrm{pH}$ is a very important factor as it contributes to the WHC and therefore quality characteristics of cooked meat products, which will be clarified below.

Emulsion stability and cooking loss of cooked sausages

Significant $(\mathrm{p}<0.05)$ differences in emulsion stability and cooking loss were found between phosphate types (Table 2). Control preparations resulted in high percentage of total expressible fluid (TEF), which indicates low emulsion stability and high cooking loss, probably due to the inability to hold water because the actomyosin complex is still intact. Polyphosphates, such as SHMP, result in a significant $(\mathrm{p}<0.05)$ decrease in cooking loss. This decrease can be explained by the increase in ionic strength by forming polyelectrolytes in water, causing electrostatic repulsion between the meat proteins, and increasing WHC. TSPP and STPP showed significantly $(\mathrm{p}<0.05)$ low TEF, indicating the best emulsion stability, as well as the lowest cooking loss. Due to the ability of di- and triphosphates to remove the structural barricade and chelate protein-bound $\mathrm{Mg}^{2+}$ and $\mathrm{Ca}^{2+}$ between meat proteins, myosin is released and can possibly act as a natural emulsifier. More proteins could be extracted and help to stabilize the protein matrix wherein fat and water are trapped. This effect, in addition to their high $\mathrm{pH}$ and their ability to affect ionic strength, presumably explains superior TSPP and STPP emulsion stability and significantly $(p<0.05)$ lower cooking loss. SAPP is also a diphosphate, which is able to dissociate the actomyosin complex, albeit possibly to a lesser extent than TSPP and STPP, as suggested by the structural characterization of the meat batter (see above). Also, in contrast to TSPP and STPP, SAPP addition results in a $\mathrm{pH}$ decrease, which decreases WHC. This may explain the lower emulsion stability and higher cooking loss caused by SAPP addition than the addition of TSPP and STPP. Finally, monophosphates are not able to dissociate the actomyosin complex. Still, DSP and TSP are able to reduce cooking loss with respect to the control. This is probably caused by the increase in $\mathrm{pH}$ after the addition of these phosphates. On the other hand, MSP addition results in the most detrimental product stability, which is probably related to slight acidification caused by this phosphate.

In another study, TSPP and STPP significantly increased $\mathrm{pH}, \mathrm{WHC}$, improved emulsion stability and decreased cooking loss of cooked patties (22), which corresponds well with the results in this study.

\section{Colour of cooked sausages}

Data in Table 2 show that phosphate type significantly $(\mathrm{p}<0.05)$ affected the cooked sausage colour parameters; however, differences in $L^{*}, a^{*}$ and $b^{*}$ values among the different formulations were rather small.

Product quality is partly determined by the appearance of cooked meat products in which a stable colour is an important criteria for the consumers' acceptance. Nitrite is added to cured meat products like cooked sausages. Together with the pigment myoglobin, nitrosomyoglobin is produced and is responsible for the dark red colour of cured meat that has not been heated. When nitrosomyoglobin is exposed to heat during cooking, nitrosohemochrome is formed, which has a typical pink colour, characteristic for cured cooked meat products. Based on our results, it seems that after cooking, no specific type of phosphate should be chosen or avoided to obtain specific colour characteristics. The addition of TPP, TSPP and blends had no effect on the colour characteristics of goat meat products (26), which is in line with our results.

\section{Effect of phosphate type on textural properties of cooked sausages}

Data in Table 2 show that only MSP and SAPP significantly $(\mathrm{p}<0.05)$ increased hardness of cooked sausages compared to the control. The other phosphate types, such 
as TSPP, STPP, etc. (Table 2$)$ did not significantly $(\mathrm{p}<0.05)$ influence hardness compared to the control.

Texture is, apart from colour and jelly separation, also an important factor for consumers' acceptability (3). Hardness can be influenced by several factors (30). First, when the extractability of myofibrillar proteins is enhanced, more proteins are available for emulsification and are able to form a more stable gel matrix during heating, which could increase hardness. On the other hand, hardness can also increase due to water or fat loss during processing and storage, which is detrimental to the product quality. In our study, hardness of the preparation with MSP significantly $(\mathrm{p}<0.05)$ increased. Addition of MSP also resulted in the greatest cooking loss and the lowest emulsion stability (highest TEF, Table 2). This may explain the increased hardness compared to the sausages with other phosphate types. SAPP has, just like MSP, a low $\mathrm{pH}$ value (2). However, emulsion stability and cooking loss were not as detrimental as in the case of MSP. This was possibly due to the fact that SAPP, which is a diphosphate, is able to dissociate the actomyosin complex, extract myofibrillar proteins and enhance emulsifying and gelling properties, which could also enhance hardness of meat products.

Therefore, it is assumed that hardness is affected by both a good extractability and water and fat loss, as also stated previously (30).

Despite the statistical differences, changes in hardness between the different formulations of sausages were relatively small. Therefore, it can be concluded that phosphate type had little impact on the sausage textural properties.

TSPP and STPP enhanced texture of cooked patties, while SAPP and SHMP had little effect (21). However, results are difficult to compare among the different types of meat products that were evaluated.
Selection of phosphate type for further analyses

The best results with regard to the structural properties and stability (emulsion stability and cooking loss) were obtained with TSPP (diphosphate) and STPP (triphosphate). Diphosphate and triphosphate perform similarly and are excellent functional ingredients for use in meat products (20). Compared to the other phosphate types, TSPP is superior in dissociating the actomyosin complex (3). Therefore, the authors decided to select TSPP as the most promising phosphate for the manufacturing of cooked sausage with the best quality characteristics. TSPP was used as the standard phosphate during the second part of research, in which the amount of TSPP was gradually reduced.

\section{Impact of different mass fractions of TSPP on the quality characteristics of cooked sausages}

Structural properties of meat batters with TSPP

Structural properties were also significantly $(\mathrm{p}<0.05)$ influenced by the mass fraction of phosphate (Table 3 ). LVR and $G^{*}$ of sausage batters significantly $(\mathrm{p}<0.05)$ decreased with increasing phosphate mass fraction, reaching a plateau at $0.06 \%$. The highest values of LVR and $G^{*}$ were obtained when the control was used, probably because in this case the actomyosin complex was still intact, which led to a 'stronger' system and a higher resistance to deformation. LVR and $G^{*}$ decreased rapidly with increasing mass fractions of added TSPP, which may be attributed to the fact that TSPP acts strongly on the actomyosin complex due to its chelating characteristics and ability to split the actomyosin complex. The $\delta$ significantly increased with increasing phosphate mass fraction, also reaching a plateau at $0.06 \%$. The lower $\delta$ at lower phosphate content presumably indicates that the system showed more liquid-like behaviour. No other studies concerning structural properties related to the amount of phosphate were found.

Table 3. Significant differences at $\mathrm{p}<0.05$ of the physicochemical (colour and $\mathrm{pH}$ ) and quality characteristics (structural and textural properties, emulsion stability and cooking loss) of pork sausages with different mass fractions of TSPP $(N=3)$

\begin{tabular}{|c|c|c|c|c|c|c|}
\hline$w\left(\mathrm{P}_{2} \mathrm{O}_{5}\right) / \%$ & 0.17 & 0.11 & 0.06 & 0.03 & 0.01 & 0 \\
\hline \multicolumn{7}{|c|}{ Structural properties } \\
\hline $\mathrm{LVR} / \mathrm{Pa}$ & $(6.60 \pm 0.86)^{\mathrm{d}}$ & $(6.18 \pm 0.40)^{\mathrm{d}}$ & $(8.41 \pm 0.58)^{\mathrm{d}}$ & $(14.8 \pm 1.6)^{c}$ & $(23.6 \pm 3.0)^{\mathrm{b}}$ & $(34.9 \pm 4.7)^{\mathrm{a}}$ \\
\hline$G^{*} / 10^{1} \mathrm{~Pa}$ & $(288 \pm 45)^{\mathrm{d}}$ & $(254 \pm 51)^{\mathrm{d}}$ & $(296 \pm 32)^{d}$ & $(410 \pm 57)^{c}$ & $(514 \pm 22)^{b}$ & $(733 \pm 40)^{a}$ \\
\hline$\delta /^{\circ}$ & $(29.4 \pm 1.4)^{\mathrm{a}}$ & $(28.3 \pm 2.4)^{\mathrm{ab}}$ & $(28.60 \pm 0.92)^{\mathrm{a}}$ & $(26.11 \pm 0.98)^{\mathrm{b}}$ & $(22.91 \pm 0.24)^{c}$ & $(13.26 \pm 0.35)^{\mathrm{d}}$ \\
\hline \multicolumn{7}{|l|}{ Stability } \\
\hline $\mathrm{TEF} / \%$ & $(6.6 \pm 1.2)^{\mathrm{bcd}}$ & $(7.4 \pm 2.2)^{\mathrm{bc}}$ & $(7.8 \pm 1.5)^{\mathrm{ab}}$ & $(5.4 \pm 1.7)^{\mathrm{cd}}$ & $(5.1 \pm 1.8)^{\mathrm{d}}$ & $(9.9 \pm 2.0)^{\mathrm{a}}$ \\
\hline $\mathrm{CL} / \%$ & $(0.65 \pm 0.40)^{\mathrm{b}}$ & $(0.71 \pm 0.27)^{\mathrm{b}}$ & $(1.06 \pm 0.24)^{\mathrm{b}}$ & $(0.51 \pm 0.30)^{\mathrm{b}}$ & $(1.18 \pm 0.30)^{\mathrm{b}}$ & $(6.33 \pm 0.72)^{\mathrm{a}}$ \\
\hline \multicolumn{7}{|c|}{ Physicochemical properties } \\
\hline$L^{*}$ & $(76.11 \pm 0.53)^{\mathrm{b}}$ & $(75.86 \pm 0.33)^{\mathrm{b}}$ & $(76.15 \pm 0.24)^{\mathrm{b}}$ & $(75.37 \pm 0.33)^{c}$ & $(75.87 \pm 0.31)^{\mathrm{b}}$ & $(76.66 \pm 0.43)^{a}$ \\
\hline$a^{*}$ & $(8.25 \pm 0.23)^{\mathrm{a}}$ & $(8.27 \pm 0.17)^{\mathrm{a}}$ & $(8.21 \pm 0.20)^{\mathrm{a}}$ & $(8.16 \pm 0.98)^{\mathrm{a}}$ & $(8.27 \pm 0.18)^{\mathrm{a}}$ & $(8.12 \pm 0.28)^{\mathrm{a}}$ \\
\hline$b^{*}$ & $(12.47 \pm 0.26)^{\mathrm{ab}}$ & $(12.66 \pm 0.24)^{\mathrm{a}}$ & $(12.48 \pm 0.29)^{\mathrm{ab}}$ & $(12.57 \pm 0.14)^{\mathrm{ab}}$ & $(12.19 \pm 0.25)^{\mathrm{c}}$ & $(12.39 \pm 0.24)^{\mathrm{bc}}$ \\
\hline $\mathrm{pH}$ & $(6.44 \pm 0.05)^{\mathrm{a}}$ & $(6.30 \pm 0.02)^{\mathrm{b}}$ & $(6.13 \pm 0.03)^{c}$ & $(6.26 \pm 0.04)^{b}$ & $(6.17 \pm 0.06)^{c}$ & $(6.01 \pm 0.11)^{\mathrm{d}}$ \\
\hline \multicolumn{7}{|c|}{ Textural properties } \\
\hline Hardness/N & $(7.8 \pm 0.9)^{\mathrm{abc}}$ & $(8.2 \pm 1.1)^{\mathrm{ab}}$ & $(8.6 \pm 1.0)^{\mathrm{a}}$ & $(7.2 \pm 1.2)^{\mathrm{bc}}$ & $(7.0 \pm 1.1)^{\mathrm{c}}$ & $(8.2 \pm 1.5)^{\mathrm{a}}$ \\
\hline
\end{tabular}

LVR=linear viscoelastic region, $G^{*}=$ complex modulus, Eq. $1, \delta=$ phase angle, TEF=total expressible fluid, Eq. 2, CL=cooking loss, Eq. 3, $L^{*}=$ lightness, $a^{*}=$ redness and $b^{*}=$ yellowness 
Influence of TSPP mass fraction on $\mathrm{pH}$ of cooked sausages

Phosphate mass fraction significantly $(\mathrm{p}<0.05)$ influenced the $\mathrm{pH}$ of cooked sausages (Table 3). Generally, lowering phosphate mass fraction decreased $\mathrm{pH}$. This was expected since the $\mathrm{pH}$ value of TSPP is high (10.2 in a $1 \%$ solution (2)) and higher amounts of TSPP presumably increase $\mathrm{pH}$ compared to the control with a $\mathrm{pH}=6.01$.

The $\mathrm{pH}$ of patties increased progressively with increasing level of phosphate (TSPP, STPP and blends were used) (22), which is in line with our results.

Influence of TSPP mass fraction on emulsion stability and cooking loss of cooked sausages

Data in Table 3 show that phosphate mass fraction significantly $(\mathrm{p}<0.05)$ affected cooking loss and emulsion stability (lower TEF). Phosphate elimination resulted in high cooking loss compared to the preparations with added phosphate. Phosphate reduction also had a negative effect on emulsion stability and resulted in higher percentage of TEF; however, this effect was less obvious. Even the smallest amount of TSPP led to a tremendous decrease in cooking loss and, however less pronounced, better emulsion stability. TSPP can dissociate the actomyosin complex (3), and therefore, probably more myofibrillar proteins were extracted, which possibly led to an improved emulsification of fat droplets and a stronger gel network formation during heating.

The $\mathrm{pH}, \mathrm{WHC}$ and emulsion stability of patties increased progressively with increasing level of phosphate, while cooking loss decreased (22), which is in line with our results.

Influence of TSPP mass fraction on colour of cooked sausages

As already discussed in the first part, the impact of phosphate on colour was rather limited. Data in Table 3 indicate that $L^{*}, a^{*}$ and $b^{*}$ showed no clear trend as a function of phosphate mass fraction.

Influence of TSPP mass fraction on textural properties of cooked sausages

Hardness of cooked sausages was not influenced when the mass fraction of TSPP was reduced from 0.17 to $0.06 \%$, but a further reduction in its dosage resulted in a small but significant decrease (Table 3 ). This was possibly due to the fact that TSPP levels lower than $0.06 \%$ were not able to dissociate the actomyosin complex, extract myofibrillar proteins and enhance emulsifying and gelling properties, which in their turn could increase hardness of meat products. In contrast, the control that does not contain TSPP showed an unexpectedly high hardness, which is probably due to the higher cooking loss $(6.33 \%)$ of the control than of the cooked sausages prepared with TSPP (cooking loss 0.51 to $1.18 \%$ ). The control contained less water, which resulted in a firmer product. Overall, hardness of all cooked sausages ranged from 7.0 to $8.6 \mathrm{~N}$ and therefore, the effect of mass fraction of TSPP on hardness of cooked sausages can be considered as rather limited.

Cooked poultry breast meat batters with $2 \% \mathrm{NaCl}$ and $0.5 \%$ phosphate showed the highest values of all tex- tural parameters in comparison with meat batters without phosphate (20). However, results are difficult to compare due to the different type of meat.

\section{Conclusion}

The aim of this study was to reduce the amount of phosphate in emulsified meat products with minimal loss of product quality. First, 7 different phosphate types were evaluated. Tetrasodium pyrophosphate (TSPP), a diphosphate, and sodium tripolyphosphate (STPP), a triphosphate, increased $\mathrm{pH}$, improved structural properties, resulted in the highest emulsion stability and lowest cooking loss and had little effect on textural properties. It was shown that measuring the dynamic viscoelastic properties is a very useful tool to evaluate the quality of meat products, as this method gives insight in the structure of the meat product and especially the functional properties of meat proteins. Based on the structural properties, a minimum mass fraction of $0.06 \%$ was sufficient to obtain an acceptable qualitative product. However, the exact minimal amount of phosphate needed to obtain good product quality probably depends on the product composition.

In summary, this study shows that the current amount of phosphate added to emulsified meat products can be significantly reduced with minimal loss in product quality. However, in order to maintain product quality without any phosphate added, alternative ingredients such as functional protein are needed. This will be the subject of a future study.

\section{Acknowledgements}

The authors acknowledge the financial support from Flanders'FOOD (Instituut voor Innovatie door Wetenschap en Technologie) and the support from the Flemish meat industry and its suppliers.

\section{References}

1. Ritz E, Hahn K, Ketteler, M, Kuhlmann MK, Mann J. Phosphate additives in food - a health risk. Dtsch Arztebl Int. 2012;109:49-55.

http://doi.org/10.3238/arztebl.2012.0049

2. Bach Son Long NH, Gál R, Buňka F. Use of phosphates in meat products. Afr J Biotechnol. 2011;10:19874-82.

https://doi.org/10.5897/ajbx11.023

3. Feiner G. Meat products handbook - practical science and technology. Cambridge, UK: Woodhead Publishing Limited; 2006.

https://doi.org/10.1533/9781845691721

4. European Food Safety Authority (EFSA). Assessment of one published review on health risks associated with phosphate additives in food. EFSA J. 2013;11:3444-71. https://doi.org/10.2903/j.efsa.2013.3444

5. Fernández-Martín F, Cofrades S, Carballo J, Jiménez-Colmenero F. Salt and phosphate effects on the gelling process of pressure/heat treated pork batters. Meat Sci. 2002;61:1523. https://doi.org/10.1016/S0309-1740(01)00157-7

6. Molins RA. Phosphates in food. Boca Raton, FL, USA: CRC Press; 1991. 
7. Puolanne E, Halonen M. Theoretical aspects of water-holding in meat. Meat Sci. 2010;86:151-65. https://doi.org/10.1016/j.meatsci.2010.04.038

8. Barbut S. Importance of fat emulsification and protein matrix characteristics in meat batter stability. J Muscle Foods. 1995;6:161-77. https://doi.org/10.1111/j.1745-4573.1995.tb00564.x

9. Gordon A, Barbut S, Schmidt G. Mechanism of meat batter stabilization: a review. Crit Rev Food Sci Nutr. 1992;32:299_ 332. https://doi.org/10.1080/10408399209527602

10. Kim JS, Schnee R, Park JW. Chemical and functional properties of various blends of phosphates. J Food Qual. 2009;32: $504-21$. https://doi.org/10.1111/j.1745-4557.2009.00265.x

11. Liu G, Xiong YL. Gelation of chicken muscle myofibrillar proteins treated with protease inhibitors and phosphates. J Agric Food Chem. 1997;45:3437-42. https://doi.org/10.1021/jf9700485

12. Wang D, Dong H, Zhang M, Liu F, Bian H, Zhu Y, Xu W. Changes in actomyosin dissociation and endogenous enzyme activities during heating and their relationship with duck meat tenderness. Food Chem. 2013;141:675-9. https://doi.org/10.1016/j.foodchem.2013.04.034

13. Desmond E. Reducing salt: a challenge in the meat industry. Meat Sci. 2006;74:188-96. https://doi.org/10.1016/j.meatsci.2006.04.014

14. Offer G, Trinick J. On the mechanism of water holding in meat: the swelling and shrinking of myofibrils. Meat Sci. 1983;8:245-81. https://doi.org/10.1016/0309-1740(83)90013-X

15. Xiong YL, Lou X, Wang C, Moody WG, Harmo RJ. Protein extraction from chicken myofibrils irrigated with various polyphosphate and $\mathrm{NaCl}$ solutions. J Food Sci. 2000;65:96100. https://doi.org/10.1111/j.1365-2621.2000.tb15962.x

16. Fernández-López J, Sayas-Barberá E, Pérez-Alvarez JA, Aranda-Catalá V. Effect of sodium chloride, sodium tripolyphosphate and $\mathrm{pH}$ on colour properties of pork meat. Colour Res Appl. 2004;29:67-74. https://doi.org/10.1002/col.10215

17. Erdogdu SB, Erdogdu F, Ekiz HI. Influence of sodium tripolyphosphate (STP) treatment and cooking time on cook losses and textural properties of red meats. J Food Process Eng. 2007;30:685-700. https://doi.org/10.1111/j.1745-4530.2007.00139.x

18. Moiseev IV, Cornforth DP. Sodium hydroxide and sodium tripolyphosphate effects on bind strength and sensory characteristics of restructured beef rolls. Meat Sci. 1997;45:53-60. https://doi.org/10.1016/S0309-1740(96)00093-9

19. Sen AR, Naveena BM, Muthukumar M, Babji Y, Murthy TRK. Effect of chilling, polyphosphate and bicarbonate on quality characteristics of broiler breast meat. Brit Poultry Sci. 2005; 46:451-6.

https://doi.org/10.1080/00071660500191072

20. Somboonpanyakul P, Barbut S, Jantawat P, Chinprahast N. Textural and sensory quality of poultry meat batter containing malva nut gum, salt and phosphate. LWT - Food Sci Technol. 2007;40:498-505. https://doi.org/10.1016/j.lwt.2005.12.008

21. Anjaneyulu ASR, Sharma N, Kondaiah N. Evaluation of salt, polyphosphates and their blends at different levels on physicochemical properties of buffalo meat and patties. Meat Sci. 1989;25:293-306.

https://doi.org/10.1016/0309-1740(89)90047-8
22. Baublits RT, Pohlman FW, Brown Jr AH, Johnson ZB. Effects of enhancement with differing phosphate types, concentrations, and pump rates, without sodium chloride, on beef biceps femoris instrumental colour characteristics. Meat Sci. 2006;72:503-12.

https://doi.org/10.1016/j.meatsci.2005.08.018

23. Baublits RT, Pohlman FW, Brown Jr AH, Johnson ZB. Effects of sodium chloride, phosphate type and concentration, and pump rate on beef biceps femoris quality and sensory characteristics. Meat Sci. 2005;70:205-14. https://doi.org/10.1016/j.meatsci.2004.12.011

24. Lee BJ, Hendricks DG, Cornforth DP. Effect of sodium phytate, sodium pyrophosphate and sodium tripolyphosphate on physico-chemical characteristics of restructured beef. Meat Sci. 1998;50:273-83. https://doi.org/10.1016/S0309-1740(98)00002-3

25. Schwartz WC, Mandigo RW. Effect of salt, sodium tripolyphosphate and storage on restructured pork. J Food Sci. 1976; 41:1266-9. https://doi.org/10.1111/j.1365-2621.1976.tb01148.x

26. Gadekar YP, Sharma BD, Shinde AK, Mendiratta SK. Effect of different phosphates on quality of goat meat and restructured goat meat products. Agric Res. 2014;3:370-6. https://doi.org/10.1007/s40003-014-0129-3

27. Ünal SB, Erdoğdu F, Ekiz HI. Effect of temperature on phosphate diffusion in meats. J Food Eng. 2006;76:119-27. https://doi.org/10.1016/j.jfoodeng.2005.04.041

28. Capita R, Alonso-Calleja C, Sierra M, Moreno B, García-Fernández M. Effect of trisodium phosphate solutions washing on the sensory evaluation of poultry meat. Meat Sci. 2002;55: 19-24. https://doi.org/10.1016/S0309-1740(00)00002-4

29. Wierbicki E, Howker JJ. Effect of salt, phosphates and other curing ingredients on shrinkage of lean pork meat and the quality of smoked processed ham. J Food Saf. 1976;41:111621. https://doi.org/10.1111/j.1365-2621.1976.tb14399.x

30. Wang P, Xu X, Zhou G. Effects of meat and phosphate level on water-holding capacity and texture of emulsion-type sausage during storage. Agr Sci China. 2009;8:1475-81. https://doi.org/10.1016/S1671-2927(08)60361-2

31. Puolanne EJ, Ruusunen MH, Vainionpää JI. Combined effects of $\mathrm{NaCl}$ and raw meat $\mathrm{pH}$ on water-holding in cooked sausage with and without added phosphate. Meat Sci. 2001; $58: 1-7$. https://doi.org/10.1016/S0309-1740(00)00123-6

32. Advantage software, v. 5.5.22, TA Instruments, New Castle, DE, USA; 2013. Available from: http://www.tainstruments. com/support/software-downloads-support/downloads/.

33. Liu R, Zhao SM, Xiong SB, Xie BJ, Liu HM. Studies on fish and pork paste gelation by dynamic rheology and circular dichroism. J Food Sci. 2007;72:399-403. https://doi.org/10.1111/j.1750-3841.2007.00470.x

34. Hughes E, Cofrades S, Troy DJ. Effects of fat level, oat fibre and carrageenan on frankfurters formulated with 5, 12 and 30\% fat. Meat Sci. 1996;45:273-81. https://doi.org/10.1016/S0309-1740(96)00109-x

35. IBM SPSS Statistics, v. 22.0, IBM, Brussels, Belgium; 2016. Available from: http://www.vlhora.be/index.html.

36. Steen L, Fraeye I, De Mey E, Goemaere O, Paelinck H, Foubert I. Effects of salt and liver/fat ratio on viscoelastic properties of liver paste and its intermediats. Food Bioprocess Technol. 2014;7:496-505. https://doi.org/10.1007/s11947-012-1038-8 